\title{
Humanistic Psychology in the University Preparation of Future Teachers
}

\section{Lubica Gáborová*}

\begin{abstract}
The study shows the possibilities of humanistic psychology in conditions of university preparation of future teachers. It brings results from the research of PCA (Person-Centered Approach) principles applied at the universities.
\end{abstract}

Key words: humanistic psychology, directive, non-directive, facilitator, student.

\section{Introduction}

Humanistic psychology aims mainly at a live out personality. It looks at a man from his own, subjective view of the world, sense of himself and feeling of his own value. Its main representatives are C. R. Rogers, A. Maslow, R. May, G. Allport, C. G. Jung, A. Adler, E. Erikson, E. Fromm, A. Ellis a K. Horneyová. C. R. Rogers (1986) set the necessary and adequate conditions for a change in personality, which were formulated in his psychotherapeutic practice. He proposed that the change of personality could happen in a situation, when a man appreciates a congruent therapist and when the therapist constantly tries to understand him/her emphatically and to sustain positive relationship with him/her without questions.

The topical hypothesis of this approach is a precondition of "increasing potential of every human is released in relationship with other human. It is released when man who helps, goes through and communicates, is careful, sensitive and perceptive" (Meador Rogers, 1991, p. 9). The approach aimed at a man found the fulfillment in all areas of human effort, where the main result is the full psychical development of an individual. From this philosophy, C. R. Rogers (1986) created a concept of PCE, depicted in his work "Freedom of education for the 80 ' $\mathrm{s}$ ". He emphasized "the necessary and adequate

\footnotetext{
* Lubica Gáborová, Dubnica Technological Institute, Dubnica nad Váhom, Slovakia; lubica.gaborova@gmail.com
} 


\section{Acta Technologica Dubnicae}

volume 1, 2011, issue 2

conditions" (empathy, congruency and acceptance) in the education area. He reminds that the impact of all three conditions on a personality is enormous.

An emphatic teacher not only sympathizes with his students, but he also communicates his feelings. He tries to see the world through the student's eyes, "to walk in his shoes", to feel what a student feels. A component of empathy is the empathetic listening to a student. It is the finding of half covered student's emotions. The teacher should try to understand the student, not to judge him/her. Student's empathy could be developed in different subjects, as well as outside them. The result of such approach could be a pro-social personality.

Sufficiently strong empathy could hardly exist without the sufficient unconditional positive acceptance (Meador - Rogers, 1991). An accredited teacher positively accepts the students; his/her activity is not tied to rating and evaluating their thoughts, feelings and behavior. This kind of relationship could be called unconditional positive relationship.

The teacher's mission is the acceptance of the student's personality as a whole and not only of some of its parts. The teacher should show his willingness to accept the student with all his qualities and difficulties. It could be named an unreserved acceptance without any conditions. The teacher "feels respect of expected difficulties which are common in new curriculum" (Rogers, 1995, p. 233). The accredited teacher should accept the student as a parent does (Zelina, 1994). He does not approve each of his expressions, but shows a deep unpretended solicitude. Such a genuine attitude is minimally related to assessment. In this intimate atmosphere could be created unconditionally positive relationship.

A congruent teacher is a teacher who openly understands his/her attitudes - accepts his/her own feelings. He/she has become a real human in relationship with his students. "It is a man, not only a shapeless personalization of requests from a teaching plan" (Rogers, 1995, p. 233) It is a student, not a teacher, who judges the impact of the learned. The teacher-facilitator shares the responsibility for the teaching process with the others - the students and also with the parents or people from the community/class (Rogers, 1983, pp. 185-194).

The teacher creates the atmosphere of trust with the accomplishment of all these conditions. The teacher considers the student to be human beings who are worth trusting. In the atmosphere of trust, there is natural to develop the need of knowledge, curiosity and desire to learn. The teacher leads the education process as pleasure, with the excitement from exploration within the intellectual and also emotional sphere. Thus 


\section{Acta Technologica Dubnicae}

volume 1, 2011, issue 2

the teaching process is usually deepened, proceeds faster and penetrates into the life and behavior of students. It leads students to the whole-life education.

C. R. Rogers (1983) thinks about the traditional education and humanistic education as two poles of a continuum. On one side there is the traditional approach and on the other side there is the humanistic approach C. R. Roger said (1983) "I think every effort in education, every teacher, all education institutions could be rated on this scale." There are two strategies in PCE. "The facilitator creates psychological atmosphere, where the student is able to keep responsible leadership. The facilitator helps reduce accent on static or content results and supports the aim to the process of education" (Rogers, 1983).

In the humanistic approach, there is a man who grows and learns with significant power. In the centre there is a student, but the student's position is not easy at all. He is fully responsible for his headway. There have been determined encouraging results in the facilitation of education. Students achieved better exam results, their IQ score increased, and they reached higher level of knowledge, which has been reflected in better approach to solving problems and decision-making. Optimistic results occurred also with the students who used to have learning problems.

"Facilitated conditions" (Rogers, 1983) cause deep changes of power relationship in the education environment. The school must go through a long way from the traditional authoritative attitude to a position, where the teacher, the school management and the administration respect and value the student. They have to understand what the school experience means and they should create a real human relationship.

\section{Methodology}

The principles of the non-directive approach are addressed not only to us, but step by step, they are applied in other fields of life as well. We had the opportunity to develop this principle in our profession - in the education of university students. We tried to set up the specific educational style approved by the research. Our classes were led in a non-directive approach mainly in the following aspects:

In a relation to students:

- In the beginning of the first meeting with a non-directive group we introduced ourselves. We left the choice of information shared and the order of them up to the students. It is important to get through the silence and to give the students 


\section{Acta Technologica Dubnicae}

volume 1, 2011, issue 2

time to adjust from time to time. The final comments are the teacher's ones. It is always good to comment on the professional field, the research focus, etc.

- In the same class the students were asked to share their expectations of this seminar, or even to set up the goals to the following term.

- The syllabus was created together with the students and the options for some changes were open. It is good to propose the topics, the problem context or the background, so the students have better idea what to choose. The students also chose the topics discussed in the seminars and the topics suitable for selfstudy. The teacher decides which specific topics need to be discussed in the seminar.

- We respect a university student as a mature personality with a high level of intellectual abilities, the ability of independent decision making and acting. The content and the process of the further seminar were led by the students. They decided what problem would be discussed in the further seminar and by whom.

- We wanted every student to be in charge of the seminar at least once a term. The attendance and leading the seminar were the only conditions to obtain a credit.

- It is a student who evaluates himself/herself. His/her self-evaluation can be influenced by a feedback of his/her classmates, or the facilitator. We led the student to be sensitive to non-verbal expressions not only to the verbal evaluation.

The teacher should try to:

- Create a relationship with the students. We try to be ourselves like we are in real life, openly presenting our ideas we stand for. We are authentic in this relationship - the relationship is based on empathy, trust, authenticity and sincerity, and of course, on the acceptance of each student regardless of his/her study results or behavior.

- If the students are interested, we use various methods and techniques of empathy and congruence development, based on experience learning. Seminars should be very pro-social. 
- We help the students discover their own value, to create a positive relationship to themselves and the importance to express their own ideas.

- All students have an equal chance to participate in the process of "becoming" a teacher. We rarely use rivalry, only under the students' choice. In the problem matters we look for the solutions. We cooperate.

- We help students to facilitate the atmosphere. Even if we enter discussions, we merge with the group. The group is important, not a teacher.

- The group is joined by a unique experience. That supports the atmosphere of freedom. The thoughts, feelings and emotions are expressed much more easily when the semester is coming to the end.

Not all the students can understand immediately that for the open, friendly relationship, the teacher's cognitive skills are very important. We often discuss such matters with the students, so they can feel our faith in their abilities, and also the importance of developing these abilities by demanding activities. It stimulates the motivation of most of the students and invokes the need to educate or strengthen the self-reflection.

Looking back at our work in non-directive groups we can claim that in comparison to traditional groups there was much more humor. We experienced more relaxed atmosphere, felt frankness of the students in their interaction. Last but not least, most of the students experienced the role of the teacher. An important part of the seminar was a feedback. Students that took charge of the seminar, the other students and the facilitator could present their feelings in the education process. Everyone could show their point of view. Such moments should bring friendly and open atmosphere. The remarks should be taken as a good advice.

We should ask for the feedback from the students when the semester is over. The information is anonymous. Most students evaluated the possibility to communicate, to self-realize and to learn positively. For some of them it was an option to learn more about themselves or to know better their co-students in an unconventional situation. Some of them appreciated the possibility to try the teacher's role.

\subsection{Examined attitudes of university students}

One of the methods we tried to examine is introducing a new kind of social learning a non-directive approach in education. We were interested whether the change of education approach can lead to the change of opinion about the subject and the change of atmosphere in a group of students and whether it leads to the change of students' behavior. 


\section{Acta Technologica Dubnicae}

volume 1, 2011, issue 2

\subsection{The goal of the research}

The main goal of the research was to prove the influence of the non-directive approach within the sample of university students, since we did not find this approach in any accessible literature. We also examined whether the change in a teacher's approach would lead to students' self-reflection of the changes in their behavior - whether they became more sensitive, emphatic, congruent and accepted.

\subsection{Pool description}

Out of 210 students of the sophomore year (2nd grade), 163 students have filled out the questionnaire in the 1st class of the Social Psychology seminar and the Educational Psychology seminar. In the introduction of the questionnaire we asked about the opinions of students on both subjects. In the introduction seminar, we explained the principles of Rogers' non-directive approach in education. Students could decide how the work in their class will be established during the following term. The second choice was the traditional approach that has been previously experienced in psychology classes. After the "pros and cons" discussion, 5 groups of the students decided to continue in the traditional way (control group) and 5 groups chose the nondirective approach (experimental group).

\begin{tabular}{|l|l|l|l|}
\hline $\begin{array}{l}\text { Introduction group } \\
\text { in the beginning of the } \\
\text { semester }\end{array}$ & \multirow{2}{*}{163} & Control group at the end of the semester & 93 \\
\cline { 3 - 4 } & Experimental group at the end of the semester & 108 \\
\hline
\end{tabular}

Table 1 Research sample

\begin{tabular}{|l|l|}
\hline Introduction group in the beginning of the semester & 163 \\
\hline Control group at the end of the semester & 93 \\
\hline Total & $\mathbf{2 5 6}$ \\
\hline
\end{tabular}

Table 2 Introduction and control groups

\begin{tabular}{|l|l|}
\hline Introduction group in the beginning of the semester & 163 \\
\hline Experimental group at the end of the semester & 108 \\
\hline Total & $\mathbf{2 7 1}$ \\
\hline
\end{tabular}

Table 3 Introduction and experimental groups

\begin{tabular}{|l|l|}
\hline Control group at the end of the semester & 93 \\
\hline Experimental group at the end of the semester & 108 \\
\hline Total & $\mathbf{2 0 2}$ \\
\hline
\end{tabular}

Table 4 Control and experimental groups 


\subsection{Methodology of the research}

We used a questionnaire method in the research, which seemed to be the most appropriate one to investigate the problem. Asking the questions is one of the basic methods of educational and socio-psychological research and diagnostics. The questionnaire included scaled items, which created bipolar adjectives at a 7-grade measurement continuum with a zero, neutral view in the middle of the scale.

In the research we used the following antipole criteria:

For the assessment of the students' opinion to the Social Psychology seminar and the Educational Psychology seminar, we used the following criteria:

interesting - not interesting;

valuable - not valuable;

needed - not needed.

\subsection{Organization of the research}

The research had two phases: we gave the students an entry questionnaire in the beginning of the semester. After the administration of the questionnaire, the students split into two groups. The control group (5 seminar groups) continued to work "traditionally", as in the previous seminars and the second group (5 seminar groups) worked using the non-directive approach during the whole semester. After the credit week, the second phase followed. We gave the students the same questionnaire as in the beginning of the research. We familiarized the students with the experiment and explained the importance of their cooperation.

\subsection{Research outcomes processing}

We tried to find statistically significant differences between the analysed variables applying the statistical method - calculation of $x^{2}$. We analyzed the research data according to the type of seminar: traditional vs. non-directive.

\section{Results}

We tried to analyse the student's opinion on the psychology seminar in the following dimensions: interesting - not interesting, valuable - not valuable, needed - not needed. We used absolute numbers in the first line and the percentage in the second line. The students were profiled during their university study mainly in their major subjects. In the first phase we found out if the psychological disciplines are interesting for the students. 


\begin{tabular}{|c|c|c|c|c|c|c|c|c|}
\hline \multirow[b]{2}{*}{ GROUP } & \multicolumn{8}{|c|}{ Interest in seminars } \\
\hline & Attractive & $\begin{array}{l}\text { Very } \\
\text { interesting }\end{array}$ & Interesting & $\begin{array}{l}\text { Do } \\
\text { not } \\
\text { know }\end{array}$ & $\begin{array}{l}\text { Less } \\
\text { interesting }\end{array}$ & $\begin{array}{l}\text { Not } \\
\text { interesting }\end{array}$ & $\begin{array}{l}\text { Not very } \\
\text { interesting }\end{array}$ & $\begin{array}{l}\text { Row } \\
\text { total }\end{array}$ \\
\hline $\begin{array}{l}\text { Introduction } \\
\text { group }\end{array}$ & $\begin{array}{l}19 \\
11.7\end{array}$ & $\begin{array}{l}46 \\
28.2\end{array}$ & $\begin{array}{l}46 \\
28.2\end{array}$ & $\begin{array}{l}31 \\
19.0\end{array}$ & $\begin{array}{l}8 \\
4.9\end{array}$ & $\begin{array}{l}12 \\
7.4 \\
\end{array}$ & $\begin{array}{l}1 \\
0.6\end{array}$ & $\begin{array}{l}163 \\
60.1\end{array}$ \\
\hline $\begin{array}{l}\text { Experimental } \\
\text { group }\end{array}$ & $\begin{array}{l}42 \\
38.9 \\
\end{array}$ & $\begin{array}{l}47 \\
43.5 \\
\end{array}$ & \begin{tabular}{|l|}
14 \\
13.0 \\
\end{tabular} & $\begin{array}{l}2 \\
1.9 \\
\end{array}$ & $\begin{array}{l}0 \\
0\end{array}$ & \begin{tabular}{|l|}
2 \\
1.9 \\
\end{tabular} & $\begin{array}{l}1 \\
0.9 \\
\end{array}$ & $\begin{array}{l}108 \\
39.9 \\
\end{array}$ \\
\hline $\begin{array}{l}\text { Column } \\
\text { total }\end{array}$ & $\begin{array}{l}61 \\
22.5\end{array}$ & $\begin{array}{l}93 \\
34.3\end{array}$ & $\begin{array}{l}60 \\
22.1\end{array}$ & $\begin{array}{l}33 \\
12.2\end{array}$ & $\begin{array}{l}8 \\
3.0\end{array}$ & $\begin{array}{l}14 \\
5.2\end{array}$ & $\begin{array}{l}2 \\
0.7\end{array}$ & $\begin{array}{l}271 \\
100.0\end{array}$ \\
\hline
\end{tabular}

Table 5 Interest in psychology seminars

In accordance with the relevant literature (e.g., Rogers, 1995; Zelina, 1994), we could state that the change of a teacher's approach to students caused the change of a student's relationship to a subject taught. A student should have space for discussion with other students as well as with the teacher about the issues which are discussed during the lesson. Such approach strengthens feeling of unity and responsibility for the accepted decision (Fontana, 1997).

The most significant change in university students' minds regarding the traditional or non-directive seminars occurred in an "attractive" group. $11.7 \%$ of the students from the traditional seminars and $38.9 \%$ of the students from the non-direct seminar consider the seminars attractive which makes the difference of $27.2 \%$.

Another significant opinion shift could be seen in the comparison of positive and negative attitudes. $68.1 \%$ of the students think positively about the psychology seminars which are very attractive for them, $95.4 \%$ of the students which had the seminar conducted in a non-directive method expressed the positive attitude.

A significant difference could also be seen with the neutral opinion. There were $19 \%$ of the students in the control group, who in dimension "interesting - not interesting" expressed neutral opinion. In the experimental group there were $1.9 \%$ of the students with neutral opinion. Negative opinions expressed with institutions "not interesting" and "not very interesting" were changed from $12.9 \%$ in the control group to $2.8 \%$ in the non-directive approach group. The value $x^{2}=57.58$ in the statistical significance $p$ $<0.05$ - the difference between two groups can be considered significant. 
Figure 1 The dimension "interesting - not interesting”

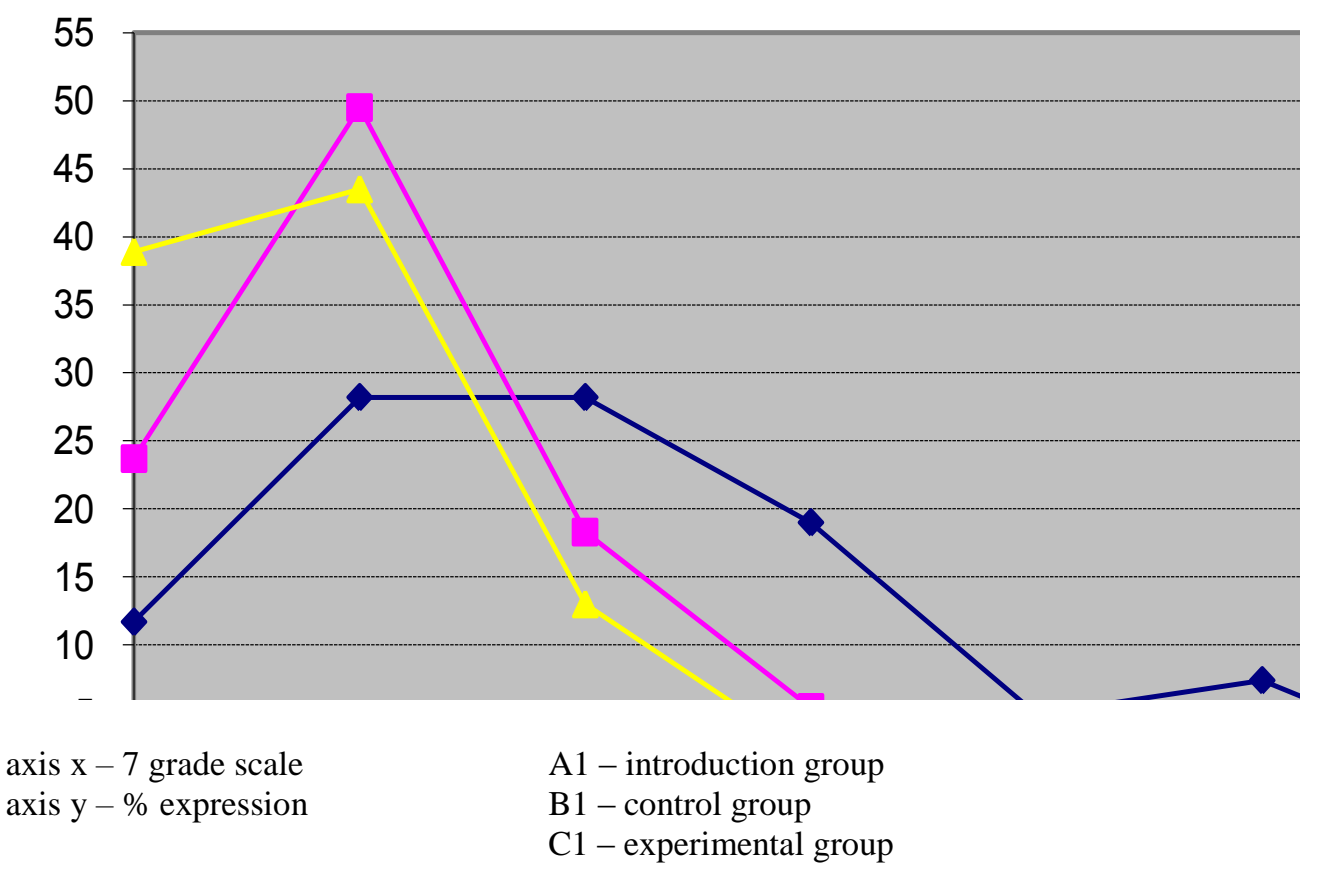

The curves which express the answers from the introduction, control and experimental groups are significantly mixed, which means that there are statistically significant differences between the groups. In spite of that we could say that the psychology seminars seem to be attractive for most of the students. The most significant positive movement occurred in the 2nd grade - very interesting and in the 4th grade - neutral opinion, which decreased significantly. However, one-semester of a non-directive approach is a fairly short period for changing the opinion.

On the basis on the above-mentioned findings, we could make a conclusion, that the students in general have significantly good attitude to the psychological disciplines, regardless of the approach applied in the seminars. The most positive opinion on the seminars could be seen in the students from the experimental group where $43.5 \%$ said, that seminars conducted in the non-directive approach were attractive, for $38.9 \%$ of the students the seminars were very interesting. There were no significant differences regarding gender and study results. 


\subsection{Value of information from psychology}

The second dimension examined was the valuability and non-valuability of information from the seminars. From the results of the students' evaluation of the program they attended we could find out whether the new approaches are more effective than the old ones and whether they could serve as suggestions for work in the following semester.

\begin{tabular}{|l|l|l|l|l|l|l|l|l|}
\hline \multirow{2}{*}{ Group } & \multicolumn{2}{|l|}{ Valuability of information } \\
\cline { 2 - 9 } & Attractive & $\begin{array}{l}\text { Very } \\
\text { valuable }\end{array}$ & Valuable & $\begin{array}{l}\text { Do not } \\
\text { know }\end{array}$ & $\begin{array}{l}\text { Less } \\
\text { valuable }\end{array}$ & $\begin{array}{l}\text { Not } \\
\text { valuable }\end{array}$ & Worthless & $\begin{array}{l}\text { Row } \\
\text { total }\end{array}$ \\
\hline $\begin{array}{l}\text { Introduction } \\
\text { group }\end{array}$ & 26 & 51 & 48 & 26 & 9 & 2 & 1 & $\mathbf{1 6 3}$ \\
\hline $\begin{array}{l}\text { Experimental } \\
\text { group }\end{array}$ & 36.0 & 31.3 & 29.4 & 16.0 & 5.5 & 1.2 & 0.6 & $\mathbf{6 0 . 1}$ \\
\hline $\begin{array}{l}\text { Column } \\
\text { total }\end{array}$ & 35.2 & 41 & 12 & 4 & 1 & 1 & 1 & $\mathbf{1 0 8}$ \\
\hline
\end{tabular}

Table 6 Valuability of information from psychology

Information was valuable for $93.5 \%$ of the students who made decision about the progress of seminars from social psychology and pedagogical psychology. Most of the students $(47.2 \%)$ considered new information very valuable. The percentage of students with neutral opinion decreased from $16 \%$ to $3.7 \%$. There were $2.7 \%$ of the students with negative opinion.

The difference between the groups showed to be significant also with $\mathrm{x}^{2}-$ test. $\mathrm{x} 2=$ 37.08 with $0.05 \%$ level of significance which is much bigger difference than between the groups lead with the traditional method.

In comparison of the results from the control and the experimental groups in the end of the semester, we found out that most of the students from both groups considered information from psychology very valuable. For $35.2 \%$ of the students from the experimental group it was attractive. Neutral opinion had $3.7 \%$ of the students from the experimental group compared to $12.9 \%$ of the students from the control group.

As we could see, the students in all three groups considered the knowledge from psychological disciplines very valuable. In comparison of the introduction and the experimental groups we found out, that the most significant change occurred in the dimension "attractive" in the experimental group. The percentage of students with neutral opinion in this group significantly decreased. At least one per cent of the students from each group considered the information from psychology worthless. We could see significant differences between the groups. 
Figure 2 The dimension "valuable - not-valuable"

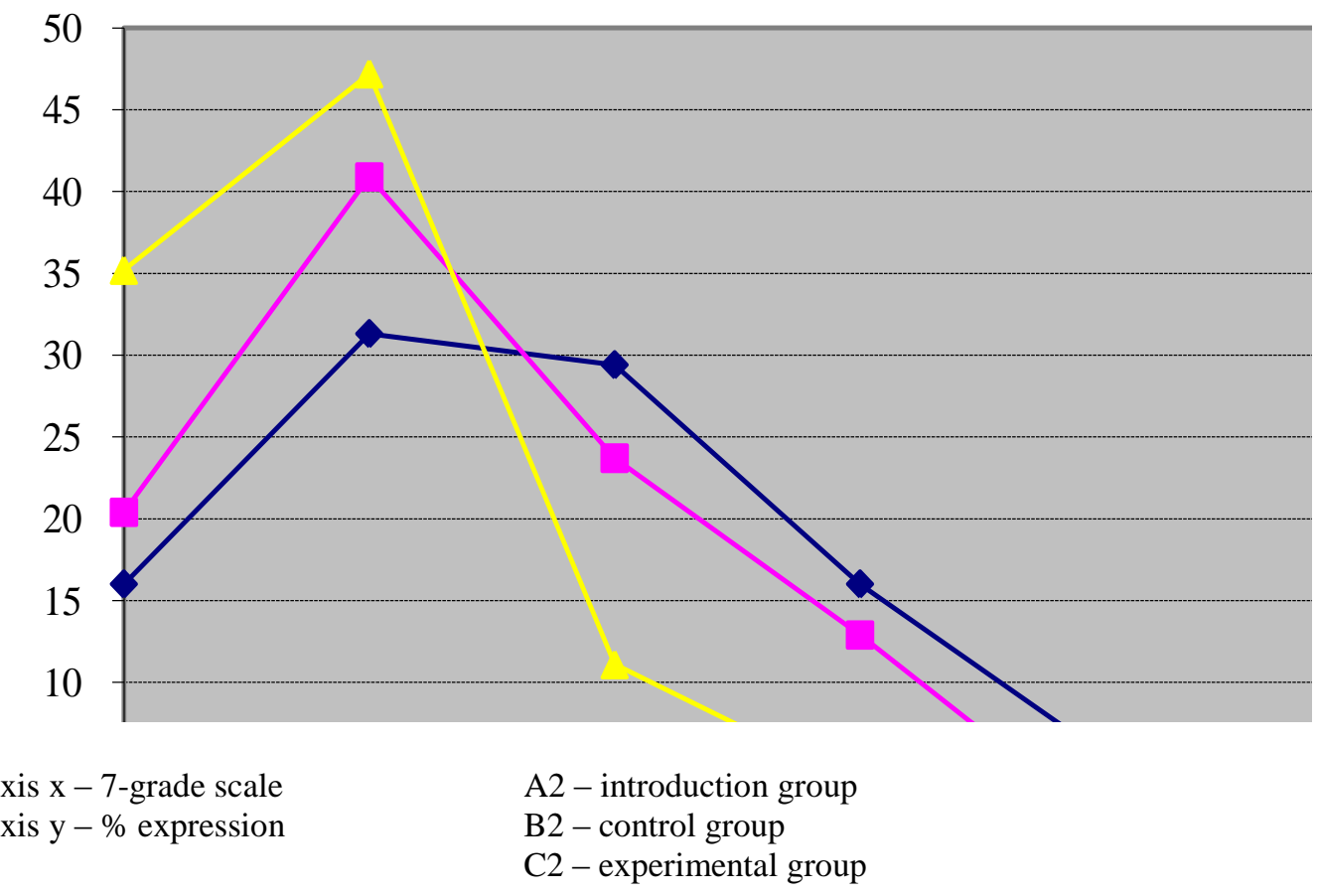

\subsection{Need of psychology in future teachers' training}

There have never been doubts about the application of psychology in education. Psychological aspects arise from the base of the educational process - the teacherstudent interaction. There still exists a problem, how big should be the extent of psychological disciplines included into the training of future teachers. There could be seen noticeable differences with using more attentive observation of the extent and the content of psychological disciplines at universities which train future teachers. The university teacher could also be a model of behavior for his students - prospective teachers. The teachers of psychology have space for creating positive interactions and friendly atmosphere in their lectures and seminars which could be used by their students in their future teaching job. 


\begin{tabular}{|l|l|l|l|l|l|l|l|l|}
\hline \multirow{2}{*}{ GROUP } & \multicolumn{2}{|l|}{ Need of psychological knowledge } \\
\cline { 2 - 9 } & Necessary & $\begin{array}{l}\text { Very } \\
\text { needed }\end{array}$ & Needed & $\begin{array}{l}\text { Do not } \\
\text { know }\end{array}$ & $\begin{array}{l}\text { More or } \\
\text { less } \\
\text { needed }\end{array}$ & $\begin{array}{l}\text { Not } \\
\text { needed }\end{array}$ & $\begin{array}{l}\text { Not } \\
\text { needed } \\
\text { at all }\end{array}$ & $\begin{array}{l}\text { Row } \\
\text { total }\end{array}$ \\
\hline $\begin{array}{l}\text { Introduction } \\
\text { group }\end{array}$ & 19 & 50 & 55 & 23 & 13 & 2 & 1 & $\mathbf{1 6 3}$ \\
\hline $\begin{array}{l}\text { Experimental } \\
\text { group }\end{array}$ & 11.7 & 30.7 & 33.7 & 14.1 & 8.0 & 1.2 & 0.6 & $\mathbf{6 0 . 1}$ \\
\hline $\begin{array}{l}\text { Column } \\
\text { total }\end{array}$ & 36 & 44 & 17 & 5 & 2 & 0 & 1 & $\mathbf{1 0 8}$ \\
\hline
\end{tabular}

Table 7 Need of psychological knowledge

Using more detailed analysis of the segmented groups, we found out that most of the students $(33.7 \%)$ considered the psychology subject to be needed for their future job. Majority of them considered it "very needed". The percentage rose up to $40.7 \%$ in the experimental group after one semester of the non-directive approach. The majority of the students considered psychology "very needed" for their future jobs. The difference between the intorduction and the experimental group is high. $\mathrm{x} 2=39.43$ with $0.05 \%$ level of significance.

Figure 3 The dimension "needed - not needed"

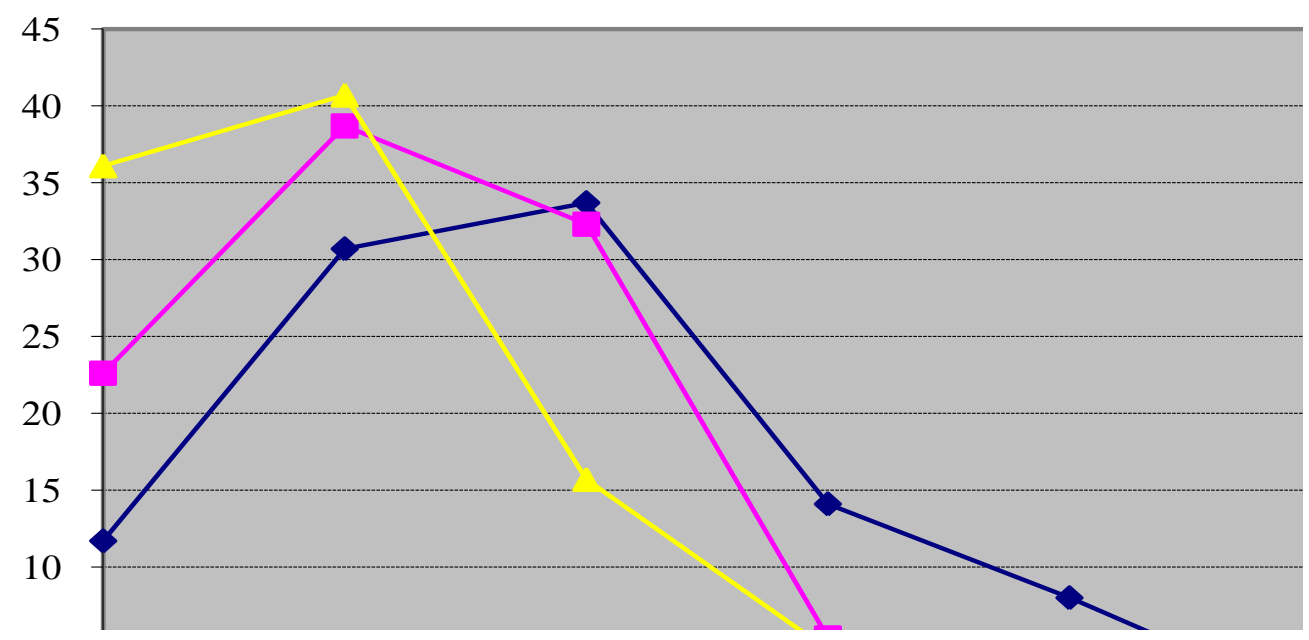

axis $\mathrm{x}-7$ grade scale axis $\mathrm{y}-\%$ expression
A2 - introduction group

$\mathrm{B} 2$ - control group

$\mathrm{C} 2$ - experimental group 


\section{Acta Technologica Dubnicae}

volume 1, 2011, issue 2

Majority of the students considered knowledge from psychology to be needed. There could be seen significant differences between the introduction and the experimental groups in neutral opinion as well. There are only minimum students who consider psychology as "not needed" in the experimental and the control groups. The change of opinion into a more positive one could be assigned to the non-directive approach at the seminars in the experimental group. With the comparison of all three groups, we found out statistically significant differences in the questionnaire results.

\section{Discussion}

We tried to find out the attitudes of the students to the psychological disciplines. We defined the attitude as opinion, judgement, convincement to things and effects and we emphasize its regulative function in human behavior.

In the study of students' attitudes we found out:

- In general, the students perceive psychological disciplines very positively. Up to $68.1 \%$ of the students after three semesters of psychology seminars assessed them at the 1st, 2nd or 3rd grade on the scale, labelled as "attractive", "very interesting" or "interesting". In the control group, the percentage increased. The most significant positive opinion change appeared among the students in the experimental group, after one semester of non-directive approach (95.4\%). We recorded the most significant change in positive opinion at the 1st grade of the scale in the dimension "attractive" with the comparison of the introduction and the experimental group. Differences between the groups were statistically significant. We detected no significant differences regarding gender and relationship.

- The students considered the knowledge from psychological disciplines mediated by the faculty attractive, very valuable or valuable. In the introduction group $76.7 \%$, in the control group $85.0 \%$ and in the experimental group $93.5 \%$ of the students. With the comparison of the introduction and the experimental group we also found out significant decrease of neutral opinion among the students of the experimental group. We found out statistically significant differences comparing the groups.

- We found out that for the majority of students - future teachers - psychology appeared as a necessary discipline, very needed or needed, what was shown with the credited percentage on the 1st, 2 nd and 3rd grade of the scale. For most students from the introduction group (33.7\%), psychology appreared 


\section{Acta Technologica Dubnicae}

volume 1, 2011, issue 2

needed, majority of students in the control group (38.7\%) considered it very needed, the same in the experimental group - some students considered psychology very needed or necessary $(36.1 \%)$. The differences between the groups are statistically significant at $0.05 \%$ level of significance.

\section{Conclusions}

The process of becoming a teacher is a long-lasting one. It may have various forms. The most important thing is the decision of a young man to become a teacher. On the long way, he meets many different approaches, models of behavior, which could guide $\mathrm{him} /$ her towards his/her aim. One of the possibilities coming out from psychotherapy is the non-directive approach in training and education. Modification of the learning process towards psychotherapy seems to be a promising possibility.

- A teacher aimed at a student is interested in teaching which is functional, has sense and which affects a student and his/her acts.

- His/her lessons are an experience for a student, which was given possibility to solve problems interesting to him/her.

- Learning will be easier, if a teacher is congruent to real life.

- A teacher accepts a student as the way he/she is. A teacher tries to understand student's feelings. He/she accepts him/her without questions.

- A teacher counts on self-actualization of a student. He/she understands the hypothesis that a student, who knows about the problems of real life, wants to learn, rise and explore and longs for knowledge and creation.

- A teacher tries to create inter-personal relations and subsequently an atmosphere in class to fulfill the natural tendencies.

It is good, when students realize, that the requirements of the non-directive approach in training and education have not been set by a teacher, but by the life itself. The teacher's role is to provide sources which help students do well both in profession and life. Let me, at the end of this study, express my conviction that students who have experienced the non-directive approach in the lessons will be predisposed to apply it in their future pedagogical practice. 


\section{Acta Technologica Dubnicae}

volume 1, 2011, issue 2

\section{References}

FONTANA, D.: Psychologie ve školni praxi. Praha: Portál, 1997.

GÁBOROVÁ, L.: Niekol'ko novších prístupov v psychologickej zložke učitel'ského vzdelávania. In Aktuálne problémy vzdelávania učitel'ov ZŠ. Prešov: PF UPJŠ, 1993, pp. 163-165.

GÁBOROVÁ, L.: Psychológia prosociálneho správania $v$ psychologickej zložke učitel'ského vzdelávania. In Problémy vzdelávania učitel’ov I. stupňa ZŠ. Banská Bystrica: UMB, 1994, pp. 48-57.

GÁBOROVÁ, L': Prístup zameraný na človeka v školstve, výchove a vzdelávaní. [Záverečná práca PGŠ Client Centred Counselling and Psychoterapy and Applications of the Person-Centered Approach]. Brno: ČIPZ, 1997, 20 p.

GÁBOROVÁ, L': Niekol'ko prístupov k humanizácii výchovného pôsobenia. In Perspektivy rozvoja vzdelanosti $v$ Prešovskom kraji v kontexte spoločenských premien a pri vstupe do 21. storočia. Prešov: FHPV PU v Prešove, 1998, pp. 207-212.

GÁBOROVÁ, L': Humanizačné trendy vo vzdelávaní vysokoškolákov. In Sociálna práca - l'udské práva - vzdelávanie dospelých. Prešov: FF PU v Prešove, 1998, pp. 287-299.

GÁBOROVÁ, L': Nondirektivny pristup vo výchove a vzdelávaní. Prešov: FHPV PU v Prešove, 2002, 95 p.

MEADOR, B. D. - ROGERS, C. R.: Prístup zameraný na človeka. Bratislava: Dom techniky ZSVTS, 1991

PIKE, G. - SELBY, D.: Globální výchova. Praha: Grada, 1994.

ROGERS, C. R.: Freedom to Learn for the 80`s. Ohio: Charles E. Merril Publishing Comp. Bell and Howell Company Columbus, 1983.

ROGERS, C. R.: A theory of therapy, personality and interpersonal relationships as developed in the client-centered framework. In Psychology: A study of a science. 3. Formulations of the person and the social context. (Ed. S. Koch). New York: McGraw-Hill, 1986, pp. 184-256.

ROGERS, C. R.: Ako byt' sám sebou. Bratislava: IRI, 1995.

ZELINA, M.: Stratégie a metódy rozvoja osobnosti. Bratislava: IRIS, 1994. 